\title{
Hubungan dan Aliran Informasi Antar Pelaku pada Klaster Batik Kota Pekalongan
}

\author{
Dwi Astuti ${ }^{1}$ \\ Pusat Pengkajian Kebijakan Difusi Teknologi \\ Badan Pengkajian dan Penerapan Teknologi, Indonesia
}

\section{Jawoto Sih Setyono}

Jurusan Perencanaan Wilayah dan Kota

Fakultas Teknik, Universitas Diponegoro, Semarang

$\begin{array}{ll}\text { Artikel Masuk } & : 1 \text { Februari } 2016 \\ \text { Artikel Diterima } & : 17 \text { April } 2016 \\ \text { Tersedia Online } & : 30 \text { April } 2016\end{array}$

\begin{abstract}
Abstrak: Potensi batik Kota Pekalongan memiliki ciri khas masing-masing sesuai inovasi yang dikembangkan masing-masing pengusaha batik sehingga perlu dilakukan kerjasama untuk mengembangkan klaster batik dengan jaringan aktor yang terlibat baik di dalam maupun di luar Kota Pekalongan. Pendekatan klaster mampu menstimulasi pengembangan inovasi batik. Penelitian ini bertujuan untuk mengetahui sejauh mana hubungan dan aliran informasi antar pelaku yang terlibat dalam jejaring kerjasama untuk mendukung pengembangan klaster batik di Kota Pekalongan. Metode penelitian menggunakan metode survei dengan pendekatan deskriptif kualitatif dan kuantitatif yang diperoleh dari sumber data sekunder dan data primer. Penelitian ini berusaha untuk memahami hubungan antar aktor yang terlibat dalam klaster batik melalui Social Network Analysis (SNA). Hasil observasi menunjukkan bahwa hubungan dan peran antar aktor memiliki hubungan yang belum optimal dan masih perlu ditingkatkan. Disperindagkop dan UMKM, Bappeda, Kementerian Perindustrian, BPPT dan Fedep Kota Pekalongan memiliki peran utama dalam pengembangan klaster batik. Kelima aktor tersebut hasil dari pengukuran degree centrality, closeness centrality dan betweeness centrality dalam jaringan. Sementara itu, sumber informasi pengetahuan yang berkaitan dengan inovasi berasal dari konsumen selain dari pengusaha batik itu sendiri. Sumber aliran informasi pengetahuan dari konsumen menunjukkan bahwa ternyata pelaku usaha lebih banyak bertukar informasi maupun sharing inovasi yang mempengaruhi terhadap proses produksi batik. Klaster batik terdiri dari multi stakeholder yang memiliki beberapa kekurangan sehingga diperlukan integrasi peran antar aktor agar proses inovasi dan teknologi sebagai strategi untuk pengembangan klaster yang inovatif.
\end{abstract}

Kata kunci: aktor, aliran informasi, jejaring, klaster industri

Abstract: Batik Pekalongan potentially has a unique characteristic developed by each entrepreneur. The relationships between entrepreneurs in order to stimulate the innovative development of batik should be examined for future development. This study aims to determine how the relationships between and information flow across the actors involved in

\footnotetext{
${ }^{1}$ Korespondensi Penulis: Pusat Pengkajian Kebijakan Difusi Teknologi, Badan Pengkajian dan Penerapan Teknologi, Indonesia Email: dwiastuti@gmail.com
} 
cooperation networks to support batik cluster development in Pekalongan. The research conducts survey method with both qualitative and quantitative approaches. The data is obtained from primary and secondary data. This study aims to understand the relationships between the actors involved in the batik cluster through Social Network Analysis (SNA). The results show that the roles of actors are still not optimal and need to be improved. Disperindagkop and UMKM, Bappeda, Ministry of Industry, and FEDEP BPPT of Pekalongan City have the major role in developing batik clusters. Their contributions are measured from techniques of centrality degree, closeness centrality, and betweenness centrality in the network. The source of batik knowledge information source comes from the both the customers and the entrepreneurs of batik. The sources of batik knowledge sharing come from the consumers useful to information exchange and innovation sharing which affect to batik production process. Batik cluster consists of multi-stakeholders carrying out some shortcomings so that it is necessary to integrate the roles of actors and the innovation process and technology as a strategy for the development of innovative clusters.

Keywords: actors, information flow, networking, industrial clusters

\section{Pendahuluan}

Pengembangan ekonomi lokal merupakan salah satu agenda pembangunan ekonomi di Indonesia. Blakely (1994) menyatakan bahwa pembangunan ekonomi lokal adalah suatu proses pembangunan ekonomi dimana pemerintah daerah dan atau kelompok masyarakat berperan aktif mengelola sumber daya alam yang dimiliki melalui pola kerjasama pihak swasta atau lainnya, menciptakan lapangan kerja, memberikan stimulasi kegiatan ekonomi pada zona perekonomiannya. Berbagai model dan program pengembangan ekonomi lokal diselenggarakan hampir di seluruh provinsi di Indonesia yang dikuatkan dengan surat edaran Kemendagri No.500/1404/V/BANGDA tentang pengembangan produk unggulan daerah yang berbasis klaster. Salah satunya provinsi Jawa Tengah melalui SK Gubernur Jateng No.500.05/30/2003 mengenai pendirian Forum Pengembangan Ekonomi dan Sumberdaya Daerah (FPESD) dan diperbaharui lagi dengan SK Gubernur Jateng No. $500.05 / 34 / 2008$ yang berlaku dari tahun 2008-2013. Menyikapi SK tersebut, maka dipilih beberapa UKM yang mampu bersaing sehingga akan mendukung penyerapan tenaga kerja dan pengembangan ekonomi lokal.

Kota Pekalongan dikenal sebagai Kota Batik, di mana Kota Pekalongan menyimpan potensi besar dalam hal pembatikan yang sudah berkembang pesat baik dalam skala kecil maupun besar. Hasil produksi batik Pekalongan menjadi salah satu penopang perekonomian kota. Industri batik memberikan kontribusi besar terhadap kemajuan perekonomian di Kota Pekalongan yang mayoritas berbentuk industri rumahan. Budaya membatik di Kota Pekalongan disebabkan faktor kekerabatan atau keturunan. Proses belajar membatik secara turun-temurun dari orang tua sebelumnya. Bahkan, akan muncul rasa malu dari anak-anak muda di lingkungan pembatik, bila mereka tidak bisa membatik. Adanya hubungan kekerabatan dan ikatan dengan lingkungan, yang menjadikan mereka memilih membatik. Industri batik memberikan sumbangan yang besar dalam kemajuan perekonomian di Kota Pekalongan dengan mayoritas dari industri rumah tangga. Kota Pekalongan memiliki kurang lebih 634 industri batik dengan daya serap sebanyak 9.944 tenaga kerja. Potensi batik yang dimiliki Kota Pekalongan berkembang sangat pesat dengan berbagai ciri khas yang dimiliki dan dikembangkan masing-masing dengan berbagai inovasi sehingga perlu dilakukan kerjasama untuk mengembangkan jaringan dengan pada pelaku yang terlibat baik di dalam maupun di luar Kota Pekalongan.

Pendekatan yang dilakukan dalam pengembangan ekonomi lokal adalah melalui pendekatan klaster industri. Klaster industri merupakan kelompok perusahaan yang saling 
berhubungan, berdekatan secara geografis dengan institusi terkait dalam suatu bidang karena kebersamaan dan saling melengkapi (Porter, 1990). Pengembangan klaster industri merupakan solusi yang dinilai efektif dalam pengembangan ekonomi lokal (Han, 2009). Hal ini dikarenakan dengan pengembangan klaster industri bukan sekedar untuk mencari keuntungan sendiri, tetapi juga semangat dalam meningkatkan keuntungan pihak lain, keuntungan bersama dan kemanfaatan yang lebih luas, klaster industri merupakan cara dimana para pelaku dapat meningkatkan difusi dan absorbsi pengetahuan sehingga terwujud adanya inovasi teknologi produk yang mampu berdaya saing. Pengembangan klaster industri merupakan konsep untuk mengoptimalkan potensi lokal yang ada, sehingga akan berdampak positif dalam pengembangan wilayah. Pendekatan klaster dianggap mampu menstimulasi inovasi melalui pertukaran informasi, pengalaman dan pengetahuan antar pelaku dalam hubungan dari hulu ke hilir serta mendorong peningkatan keterkaitan keahlian masing-masing anggota klaster (BPPT, 2003).

Inovasi memiliki makna dalam pengembangan klaster industri. Inovasi dalam klaster merupakan proses aliran dan informasi serta teknologi antar perusahaan yang ada didalamnya (Oerlemans, Meeus, \& Boekema, 2001). Jaringan inovasi terbentuk ketika ada berbagai aktor yang terlibat dalam proses inovasi dan keragaman outcome (Corsaro, Cantù, \& Tunisini, 2012). Konfigurasi jaringan mempengaruhi distribusi dan variasi informasi dan pengetahuan antar aktor (Rodan \& Galunic, 2004; Bohlmann, Calantone, \& Zhao, 2010). Pendekatan klaster industri dapat dikembangkan dalam pemberdayaan dan pengembangan UMKM karena adanya sinergitas dari mulai penyedia bahan baku sampai pada pasar, terbentuk sinergitas dari hulu ke hilir. Klaster industri mampu menstimulasi inovasi melalui pertukaran pengalaman dan pengetahuan antar pelaku dalam hubungan hulu-hilir serta mendorong peningkatan keterkaitan sosial dan peningkatan keahlian masing-masing anggota klaster. Lebih lanjut menurut Zuhal (2013) bahwa ada 2 ciri jika inovasi telah berdampak pada masyarakat, yaitu meningkatnya kemampuan IPTEK dan meningkatnya produktivitas dan pendapatan masyarakat.

Kondisi klaster batik berbeda-beda. Hasil penelitian Susanty, Handayani, dan Jati (2013) di klaster batik Pekalongan menunjukkan bahwa pengembangan klaster batik ditunjang oleh oleh beberapa hal, meliputi keberadaan industri pendukung, kondisi permintaan, persaingan usaha, dan dukungan pemerintah. Hal ini diperkuat oleh hasil penelitian Astuti (2009) menunjukkan bahwa klaster batik Pekalongan telah melakukan inovasi untuk melakukan keberlanjutan produktivitas dan daya saing dengan produk batik dari luar daerah bahkan sampai luar negeri. Inovasi yang dilakukan berupa inovasi pemasaran, inovasi bahan baku, pewarnaan dan desain. Menurut Darroch (2005) bahwa unit usaha akan lebih inovatif bila didalamnya mampu menyebarkan dan tanggap terhadap pengetahuan dan informasi yang ada. Untuk menghasilkan sebuah inovasi, tidak cukup berdasarkan ide kreatif saja, namun diperlukan tindakan yang dapat menghasilkan perubahan baru terhadap suatu organisasi. Untuk itu, perlu ada inovasi dan membangun keterkaitan dengan para pengusaha besar maupun kecil. UMKM perlu dibantu untuk membangun keterkaitan (linkage), baik dengan pengusaha, pemerintah, swasta, universitas dan lembaga pembiayaan. Di dalamnya akan memunculkan institusi lokal yang saling berbagi informasi untuk mendukung adanya pelatihan, penelitian dan infrastruktur yang mendukung pengembangan klaster. Namun demikian, akses dan transfer teknologi untuk UMKM masih menjadi tantangan yang dihadapi saat ini sehingga dibutuhkan peran dari berbagai pihak, seperti lembaga inkubator bisnis, lembaga pembiayaan, kerjasama antara lembaga riset dan perguruan tinggi serta dunia usaha untuk alih teknologi. Tantangan besar berkomunikasi dalam institusi lokal adalah bagaimana menyampaikan informasi dan bagaimana menerima informasi dari seluruh bagian dalam institusi lokal, yang sering disebut oleh proses aliran informasi (Mulyana, 2005). Pada klaster batik di Kota Pekalongan sendiri, belum ada koordinasi yang integral antara satu instansi pemerintah dengan 


\section{Hubungan dan Aliran Informasi Antar Pelaku pada Klaster Batik Kota Pekalongan}

stakeholder lain dalam pembinaan dan pengembangan klaster. Untuk itu, penelitian ini bertujuan untuk mengetahui sejauh mana hubungan dan aliran informasi antar pelaku yang terlibat dalam jejaring kerjasama untuk mendukung pengembangan klaster batik di Kota Pekalongan. Tujuan ini dapat dicapai dengan melalui tiga tahapan analisis yaitu menganalisis aktor yang terlibat dalam pengembangan klaster batik, menganalisis hubungan relasi antar aktor dalam pengembangan klaster batik dan menganalisis sumber dan aliran informasi dan pengetahuan dalam pengembangan klaster batik.

Ruang lingkup spasial dalam studi adalah klaster batik di Kota Pekalongan. Kota Pekalongan berbatasan dengan Laut Jawa di sebelah Utara, Kabupaten Pekalongan di sebelah Selatan dan Barat dan Kabupaten Batang di sebalah Timur. Dengan wilayah seluas 4.525 ha terbagi dalam 4 (empat) kecamatan yaitu Kecamatan Pekalongan Utara, Pekalongan Barat, Pekalongan Selatan dan Pekalongan Timur dengan 47 Kelurahan (Gambar 1).

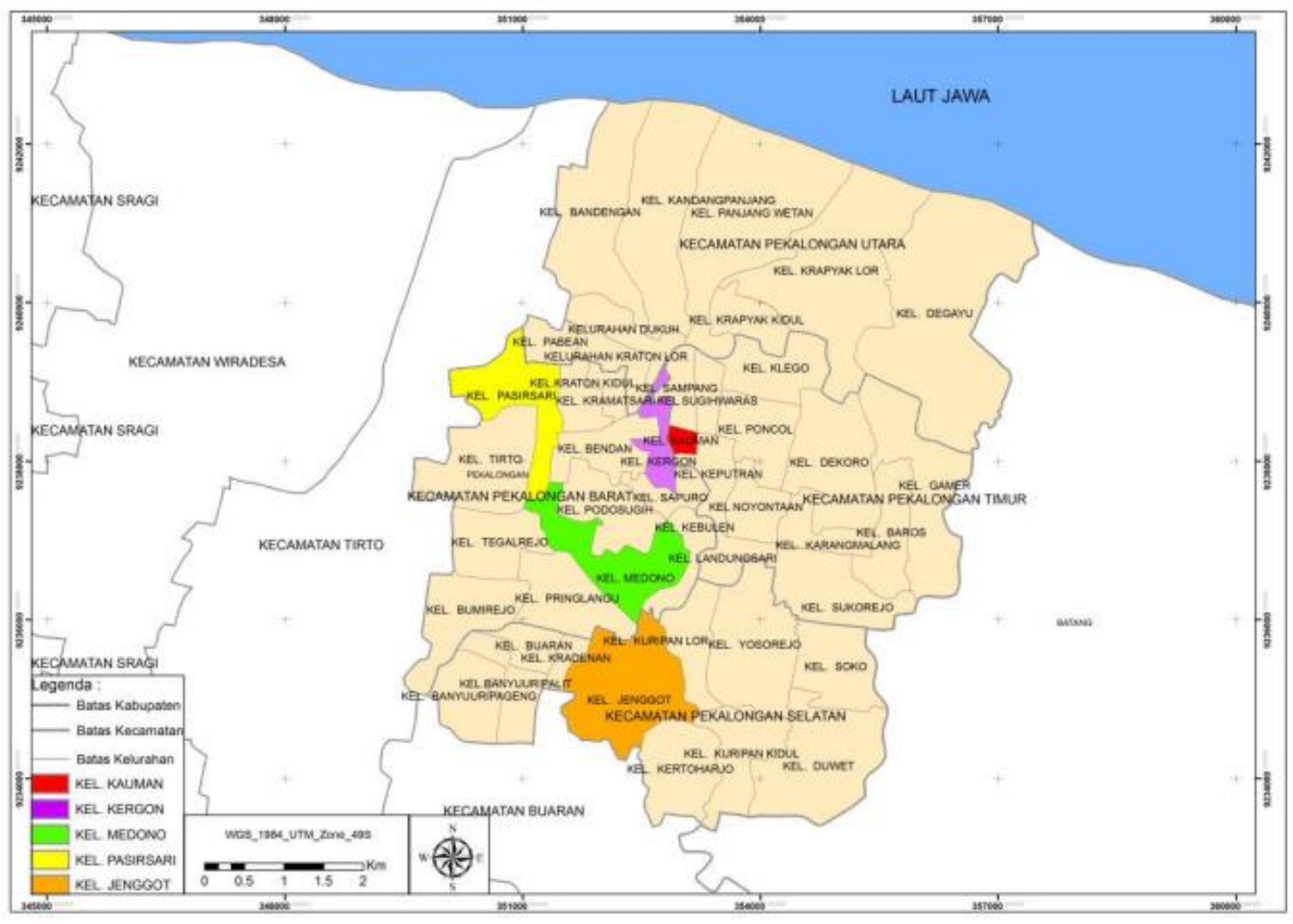

Sumber: Bappeda Kota Pekalongan, 2010

\section{Gambar 1. Peta Lokasi Studi}

\section{Metode Penelitian}

Penelitian dilakukan dengan pendekatan kualitatif dan kuantitatif. Pengumpulan data dilakukan melalui metode pengumpulan data primer dengan teknik kuesioner, observasi lapangan, dan wawancara serta pengumpulan data sekunder dengan survey instansional dan kajian pustaka. Teknik kuesioner berisi pertanyaan atau pernyataan terstruktur pada aktor/pelaku/lembaga jaringan inovasi institusi lokal yang terkait dengan pengembangan klaster industri batik. Observasi lapangan digunakan untuk mengamati kondisi fisik maupun 
nonfisik dari wilayah studi yang terkait dengan inovasi institusi lokal yang terlibat dalam klaster industri batik. Wawancara ditujukan ke beberapa pihak, meliputi pengusaha batik, forum rembug klaster, dan pengurus klaster kampung batik untuk mendapatkan gambaran informasi mengenai keterlibatan aktor dalam pengembangan klaster batik, pemetaan aktor, syarat pembentukan jaringan interaksi, dan penilaian terhadap relasi aktor. Sementara itu, survey instansional dilakukan ke Bappeda Kota Pekalongan, Dinas Perindustrian, Perdagangan, Koperasi dan UKM Kota Pekalongan, BPS Kota Pekalongan, Ristekin, Dinas Tenagakerja dan Transmigrasi Kota Pekalongan, Universitas Pekalongan, Fedep Kota Pekalongan dan Forum Rembug Klaster untuk mendapatkan gambaran mengenai pemetaan aktor yang terlibat dalam klaster batik Pekalongan.

Analisis dilakukan menggunakan analisis deskriptif kualitatif, analisis kuantitatif, analisis skoring, dan analisis jaringan sosial (Social Network Analysis). Social Network Analysis adalah teknik pemodelan interaksi sosial untuk mengidentifikasi hubungan antar aktor dalam suatu jaringan serta memahami posisi masing-masing aktor dalam mempengaruhi kondisi sumber daya dan informasi (De Fretes, Utomo, \& Manongga, 2012). Sebuah jaringan mengisyaratkan sebuah interaksi antar aktor institusi lokal, dimana interaksi hubungan yang terjadi dapat dikelompokkan menjadi hubungan yang simetris atau non-directional (dua arah) dan hubungan yang directional (satu arah). Untuk memahami pendekatan-pendekatan ini dalam analisis jaringan yang dipakai untuk mengkaji aktor atau nodes yang cukup berpengaruh dalam sebuah jaringan terdapat 3 tipe jenis bentuk jaringan yaitu star, line, circle (Hanneman \& Riddle, 2005).

Tahapan analisis terdiri dari 3 analisis, yaitu pada tahap pertama dilakukan analisis aktor yang terlibat dalam klaster batik, tahap kedua, yaitu analisis hubungan relasi yang berpengaruh dalam jaringan aktor klaster batik yang meliputi posisi aktor dalam klaster batik, seberapa jauh informasi yang bisa tersebar, dan hubungan aktor dengan aktor yang lain dalam klaster batik, dan tahap ketiga adalah analisis terhadap sumber aliran informasi dan pengetahuan. Teknik analisis deskriptif kualitatif digunakan untuk menganalisis keberadaan aktor-aktor yang terlibat, dan peranannya dalam mendukung pengembangan klaster batik Pekalongan serta mengetahui aliran sumber informasi dan pengetahuan berdasarkan hasil wawancara dan kuesioner. Sementara itu, teknik analisis deskriptif kuantitatif dilakukan untuk menganalisa hubungan relasi antar aktor yang membentukan jaringan dalam institusi lokal pengembangan klaster berdasarkan nilai skoring yang diperoleh kemudian dilakukan analisis jaringan sosial (Social Network Analysis). Dari analisis tersebut diperoleh hasil yang menginterpretasikan adanya jaringan aktor dalam klaster batik Pekalongan untuk mengetahui seberapa besar kekuatan posisi aktor di dalam jejaring interaksi dan seberapa padat jejaring yang terbentuk. Analisis pengukuran pada tingkat aktor menggunakan pendekatan tingkat keterpusatan (degree of centrality), tingkat keterhubungan (betweenness centrality), dan tingkat kedekatan jarak (closeness centrality) (Hanneman \& Riddle, 2005).

\section{Hasil dan Pembahasan}

\section{Pemetaan Aktor dalam Pengembangan Klaster Batik}

Pada perkembangan di klaster batik Kota Pekalongan terdapat beberapa aktor yang terkait dan berperan aktif dalam upaya pengembangan usaha mikro kecil dan menengah batik untuk peningkatan nilai tambah. Pada pengembangan UMKM ini terdapat dua macam kelembagaan yaitu kelembagaan murni inisiatif dari masyarakat serta kelembagaan pemerintahan. Namun, pada kenyataannya kapasitas pemerintah dirasa masih ada yang kurang dimana pemerintah memiliki keterbatasan dalam kemampuan teknis membantu 


\section{Hubungan dan Aliran Informasi Antar Pelaku pada Klaster Batik Kota Pekalongan}

para pengusaha dan juga anggaran teknologi serta SDM yang masih perlu mendapatkan pelatihan.

Keterlibatan berbagai aktor dalam pengembangan klaster batik menjadi salah satu solusi dari keterbatasan pemerintah sebagai pemegang tanggung jawab dalam meningkatkan pengembangan klaster batik di Kota Pekalongan. Adapun pengelompokan aktor yang terlibat merupakan (1) pemerintah pusat, (2) pemerintah daerah, (3) swasta, (4) lembaga litbang dan perguruan tinggi, (5) lembaga pembiayaan, (6) lembaga teknis terkait.

Munculnya aktor yang mendukung klaster batik dari adanya rantai proses aktivitas klaster yang terdiri dari pemerintah, asosiasi, lembaga keuangan, lembaga pendidikan, koperasi dan industri terkait batik. Dari hal tersebut diatas dapat diketahui baik industri, instansi maupun pihak akademisi memiliki keterkaitan yang apabila dikoordinasikan sesuai dengan fungsi dan kewenangannya dalam sebuah klaster industri batik maka hal itu akan menjadi suatu sinergi kekuatan dalam mengembangkan industri batik di Pekalongan maupun daerah lain. Tabel 1 menunjukan aktor yang terlibat dalam klaster batik serta peran masing-masing aktor.

\section{Tabel 1. Aktor yang Terlibat dalam Pengembangan Klaster Batik Kota Pekalongan}

\begin{tabular}{|c|c|c|}
\hline $\begin{array}{l}\text { Kelompok Aktor } \\
\text { Berdasarkan Teori }\end{array}$ & $\begin{array}{c}\text { Aktor yang Terlibat Dalam } \\
\text { Klaster Batik }\end{array}$ & Peran \\
\hline Pemerintah & $\begin{array}{ll}\text { - } & \text { Disperindgkop dan } \\
& \text { UMKM } \\
\text { - } & \text { Disperindag Provinsi } \\
\text { - } & \text { Bappeda } \\
\text { - } & \text { Kemenperin } \\
\text { - } & \text { BPPT } \\
\text { - } & \text { Kemenristek }\end{array}$ & 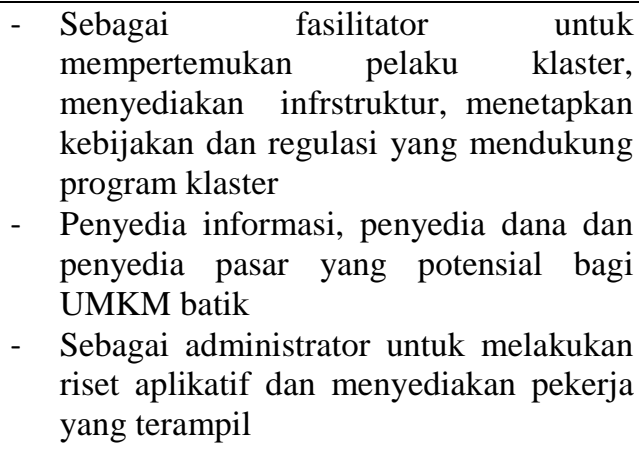 \\
\hline Swasta & $\begin{array}{ll}\text { - } & \text { PT.Telkom } \\
\text { - } & \text { Pengusaha industri batik } \\
\text { - } & \text { PT.Perhutani } \\
\text { - } & \text { Pertamina }\end{array}$ & $\begin{array}{l}\text { - Memberikan pembinaan dan } \\
\text { pendampingan terhadap pengembangan } \\
\text { klaster } \\
\text { - Fasilitasi pendanaan dan pengembagan } \\
\text { pasar }\end{array}$ \\
\hline $\begin{array}{l}\text { Lembaga } \\
\text { Pembiayaan Bank } \\
\text { maupun non Bank }\end{array}$ & $\begin{array}{ll}- & \text { Kopena } \\
- & \text { Kospin Jasa } \\
- & \text { BRI } \\
- & \text { BNI } \\
- & \text { PT.Telkom }\end{array}$ & $\begin{array}{l}\text { - Sumber dana bagi keberlangsungan } \\
\text { bisnis pembuatan batik berupa pmberian } \\
\text { pinjaman untuk investasi dan modal } \\
\text { kerja }\end{array}$ \\
\hline Akademisi & $\begin{array}{ll}\text { - } & \text { Universitas Pekalongan } \\
\text { - } & \text { Politeknik Pekalongan } \\
\text { Pusmanu } \\
\text { - } \quad \text { SMK Batik }\end{array}$ & $\begin{array}{l}\text { - Menyediakan riset pengembangan bagi } \\
\text { UKM klaster baik dalam hal produk, } \\
\text { pemasaran maupun proses produksi. } \\
\text { - Dapat mendidik tenaga kerja untuk } \\
\text { menggapai kualifikasi tertentu }\end{array}$ \\
\hline Asosiasi & $\begin{array}{ll}\text { - } & \text { BDS } \\
\text { - } & \text { Fedep Kota } \\
\text { - } & \text { Asosiasi Pecinta Batik } \\
\text { - } & \text { Paguyuban pecinta batik }\end{array}$ & $\begin{array}{l}\text { - Sebagai lembaga pendamping dan } \\
\text { pemonitor kerja pada pihak-pihak yang } \\
\text { terlibat di dalam klaster } \\
\text { - Layanan informasi pengembangan ide } \\
\text { dan strategi. } \\
\text { - } \begin{array}{l}\text { Pengembangan pasar mealui temu } \\
\text { pelaku usaha }\end{array}\end{array}$ \\
\hline
\end{tabular}


Berdasarkan Tabel 1 dapat dilihat bahwa aktor yang terlibat dalam pengembangan klaster batik Kota Pekalongan sesuai dengan pengelompokan aktor yang terlibat dalam pengelolaan pengembangan klaster batik berdasarkan teori yang ada. Aktor-aktor tersebut berada baik di dalam struktur pengelolaan pengembangan klaster batik maupun di luar struktur klaster batik. Peran aktor yang terlibat telah menciptakan lingkungan bisnis yang lebih kondusif serta memperkuat daya saing ekonomi daerah. Keterlibatan aktor dalam klaster didasarkan pada tujuan-tujuan yang berbeda-beda. Masing-masing aktor tersebut bekerjasama dalam membentuk fungsional tertentu seperti tergambarkan di Gambar 2. Klaster industri telah membuktikan mampu menciptakan peluang lebih besar dalam meningkatkan daya saing ekonomi lokal. Dalam pengembangan klaster batik terlihat bahwa peran pemerintah, swasta, akademisi, pelaku usaha, asosiasi batik dan lembaga pembiayaan dapat menjadi solusi dalam interaksi antar pelaku. Keterkaitan semua aktor akan menjadi pusat kerjasama industri batik, pemerintah dan universitas menyediakan kesempatan bersama untuk melakukan penelitian bersama sehingga menghasilkan produk yang mempunyai daya saing.

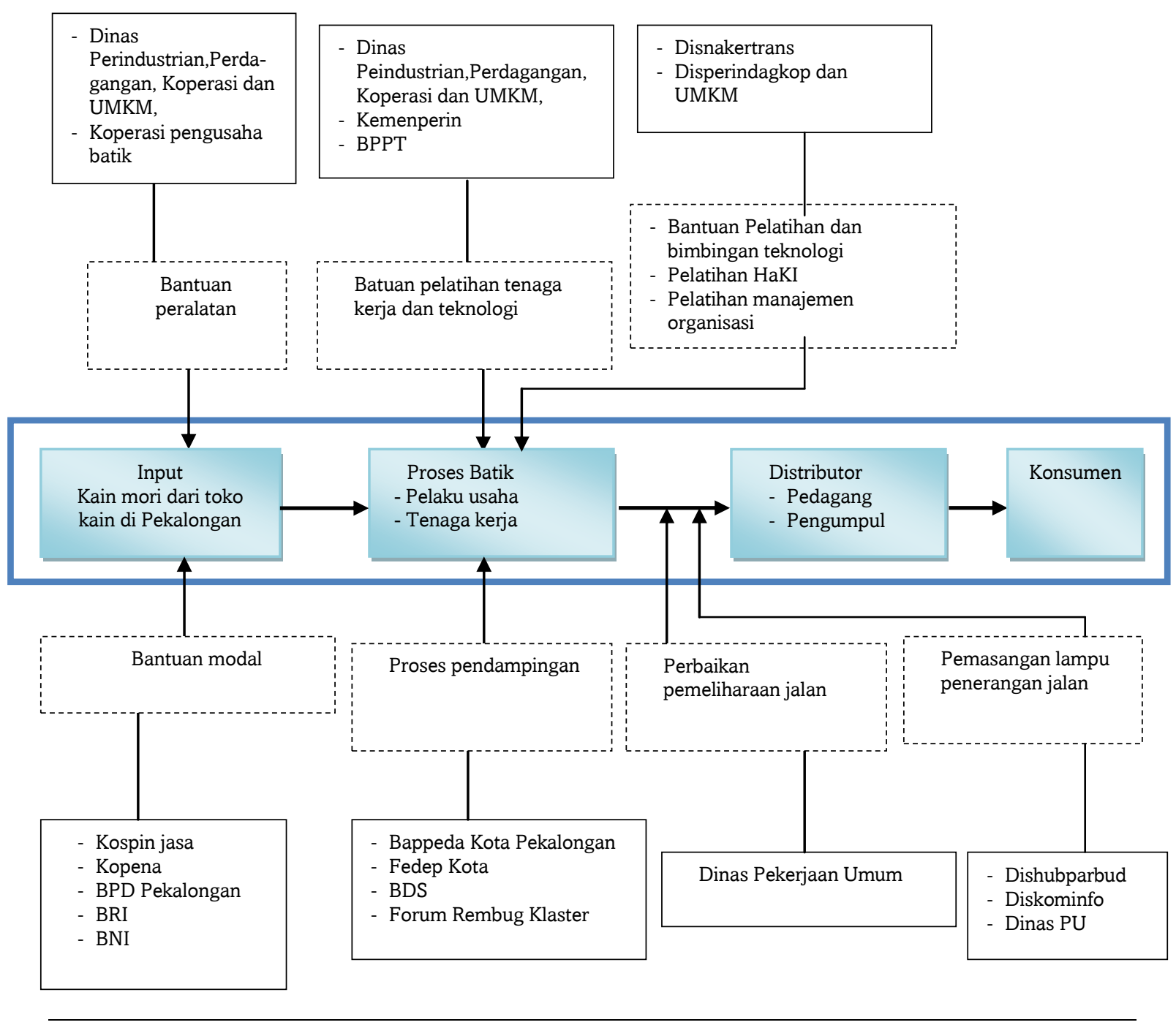

Gambar 2. Pemetaan Pelaku Klaster Batik 


\section{Analisis Relasi AntarAktor dalam Pengembangan Klaster Batik}

Analisis ini berguna untuk mengetahui hubungan atau relasi yang terjadi dalam pengembangan klaster batik. Hubungan atau relasi antar lembaga yang terkait dipetakan berdasarkan hasil survei dan kuesioner yang telah dilakukan sehingga mewakili lembaga yang terkait dalam jaringan kerjasama pengembangan klaster batik. Ini menandakan bahwa keterkaitan dan interaksi yang terbentuk dalam jaringan mempengaruhi perkembangan klaster industri batik sekaligus hal didalamnya pemecahan masalah.

1) Hubungan aktor yang terlibat dalam pengembangan klaster batik

Hubungan antar aktor dalam klaster batik akan membangun jejaring sosial sehingga akan ditemukan peran-peran tertentu dalam berbagai macam bentuk jaringan. Untuk melihat keterhubungan (connection) antar aktor dalam jejaring sosial aktor dan peran dari aktor (Centrality and Power) yang ada dalam jaringan, digunakan pengukuran density of ties dan Freeman"s Centrality Metrics, dengan melihat dari tiga perhitungan, yakni Degree Centrality, Closeness Centrality dan Betweenness Centrality (Daly \& Haahr, 2007).

Ukuran degree of centrality menunjukkan tingkat keterpusatan aktor. Penilaian keterpusatan aktor dalam hal ini menggunakan dua pendekatan, yaitu keterpusatan aktor akibat pengaruh aktor yang tinggi terhadap jejaring (dilihat berdasarkan banyaknya relasi yang diterima aktor) dan keterpusatan aktor akibat tingginya tingkat kebutuhan aktor dalam jejaring (dilihat berdasarkan banyaknya relasi yang diberikan aktor).

Hasil dari visualisasi degree centrality dalam dilihat pada Gambar 3 yang merupakan visualisasi dari seluruh aktor informasi dan pengetahuan yang diperoleh berdasarkan sentralitas untuk aliran pengetahuan menunjukkan aktor yang memiliki jumlah relasi yang besar berdasarkan gambar tersebut tampak Disperindagkop dan UKM, Bappeda, Kemenperin dan BPPT digambarkan dengan ukuran yang relatif besar dibanding aktoraktor lainnya.

Hasil perhitungan degree centrality yang memperlihatkan kecenderungan apakah setiap aktor/nodes memiliki kemampuan untuk mempengaruhi jaringan (network) secara umum, dapat dilihat dari nilai in-degree dan out degree menunjukkan bahwa Nilai network degree centrality index in-degree. $54.441 \%$ dan network degree centrality index outdegree: $54.441 \%$ ini mengindikasikan bahwa sentralisasi dalam jaringan (network centrality) secara keseluruhan tinggi, ini dapat dilihat dari hasil dimana nilainya dibawah diatas 50\%, walaupun nilainya masih mendekati 50\%. Hal ini menunjukkan bahwa pengaruh masing-masing aktor/nodes dalam jaringan bervariasi setiap aktor/nodes cenderung memiliki kemampuan untuk mempengaruhi jaringan aktor secara umum. Hasil analisis sentralitas derajat menemukan bahwa aktor-aktor Disperindagkop dan UMKM, Bappeda, Kemenperin, BPPT merupakan aktor sentral di dalam struktur jaringan ditandai dengan jumlah hubungan/relasi yang dimiliki, sedangkan Lembaga Pendidikan, Asosiasi dan lembaga pembiayaan relatif masih kecil memainkan peran dipandang dari aspek relasi/aliran pengetahuan. Lebih lanjut, hasil analisis sentralitas derajat 7 aktor yang mewakili masing-masing kelompok Pemerintah daerah, Pemerintah pusat, Asosiasi dapat dilihat pada Tabel 3. Hasil perhitungan pada Tabel 3 menunjukkan bahwa peran Disperindagkop dan UMKM merupakan aktor yang sangat diperlukan untuk kemajuan program klaster batik di Kota Pekalongan. 


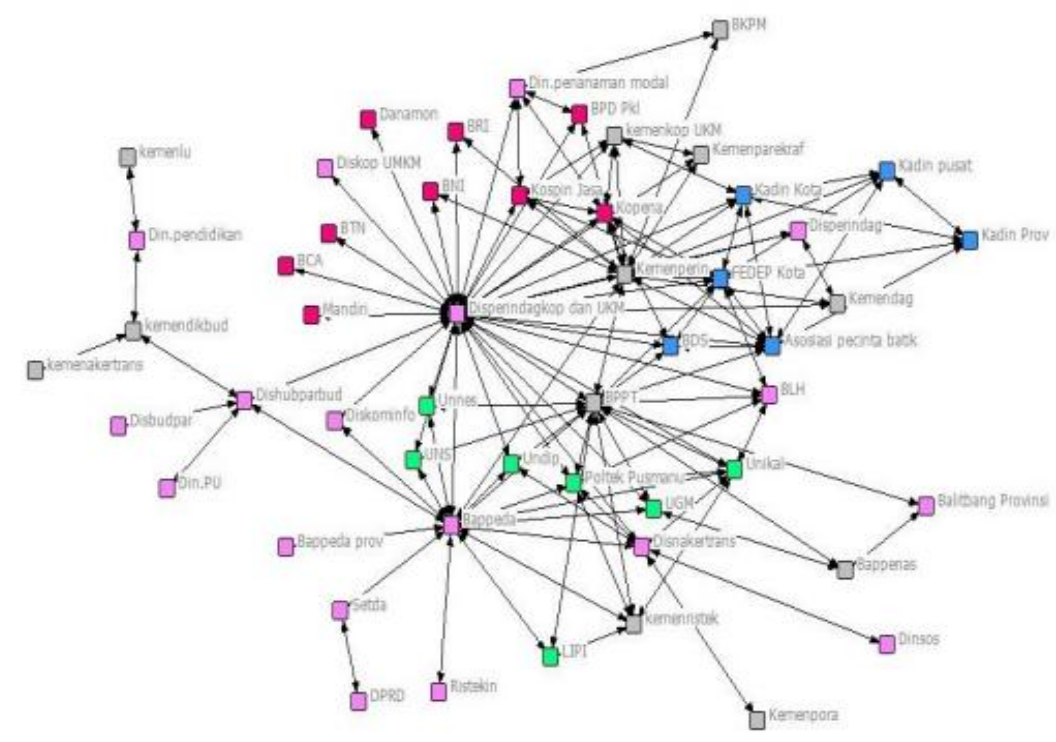

Keterangan
Pemerintah Pusat
Pemerintah Daerah
Lembaga
Asosiasi
Lembaga
Litbang
Pembiayaan

\section{Gambar 3. Visualisasi Jaringan Antar Aktor dalam Klaster Batik pada Ukuran in Degree Centrality}

Tabel 3. Hasil Perhitungan In-Degree Centrality Aktor Klaster Batik

\begin{tabular}{clcc}
\hline No & \multicolumn{1}{c}{ Aktor/ Lembaga } & Degree & Non Degree \\
\hline 1 & Disperindagkop dan UKM & 32 & 62,745 \\
2 & Bappeda & 17 & 33,333 \\
3 & Kemenperin & 17 & 33,333 \\
4 & BPPT & 17 & 33,333 \\
5 & FEDEP Kota & 11 & 21,569 \\
6 & Asosiasi Pecinta Batik & 9 & 17,647 \\
7 & Kopena & 8 & 15,686 \\
\hline
\end{tabular}

2) Kemampuan aktor dalam mengakses informasi pada klaster batik

Closeness centrality didasarkan pada total jarak antara satu titik dan semua simpul lainnya, dimana jarak yang lebih besar menghasilkan skor closeness centrality rendah. Semakin dekat simpul dengan simpul lainnya informasi lebih mudah dapat dicapai maka semakin tinggi sentralitasnya. Hasil dari visualisasi in closeness centrality dapat dilihat pada Gambar 4 dari seluruh data sampel yang diperoleh dari responden.

Hasil analisis closeness centrality ditunjukkan di Tabel 4. Melalui Tabel 4 diberikan pemahaman bahwa Hasil analisis closeness centrality pada Tabel 4 menunjukkan jaringan aktor dalam hubungan relasi aliran informasi dan pengetahuan aktor dengan nilai terendah adalah Disperindagkop dan UMKM sebesar 75.00, Bappeda dengan nilai 90, dan BPPT dengan nilai 98. Nilai ini menunjukkan bahwa aktor yang mempunyai lintasan/jarak yang pendek (nilai terendah) mempunyai kemudahan dan kedekatan untuk saling berkomunikasi sehingga memudahkan dalam penyebaran informasi untuk mendapatkan inovasi yang diperlukan pelaku usaha batik. 
Tabel 4. Hasil Perhitungan In-Closeness Centrality Aktor Klaster Batik

\begin{tabular}{clcc}
\hline No & \multicolumn{1}{c}{ Aktor/ Lembaga } & Degree & Non Degree \\
\hline 1 & Disperindagkop dan UKM & 75 & 68 \\
2 & Bappeda & 90 & 56,667 \\
3 & BPPT & 98 & 52,041 \\
4 & Kemenperin & 98 & 52,041 \\
5 & Dosbudparbud & 106 & 48,113 \\
6 & FEDEP Kota & 108 & 47,222 \\
7 & Poltek Pusmanu & 109 & 46,789 \\
8 & Unikal & 109 & 46,789 \\
\hline
\end{tabular}

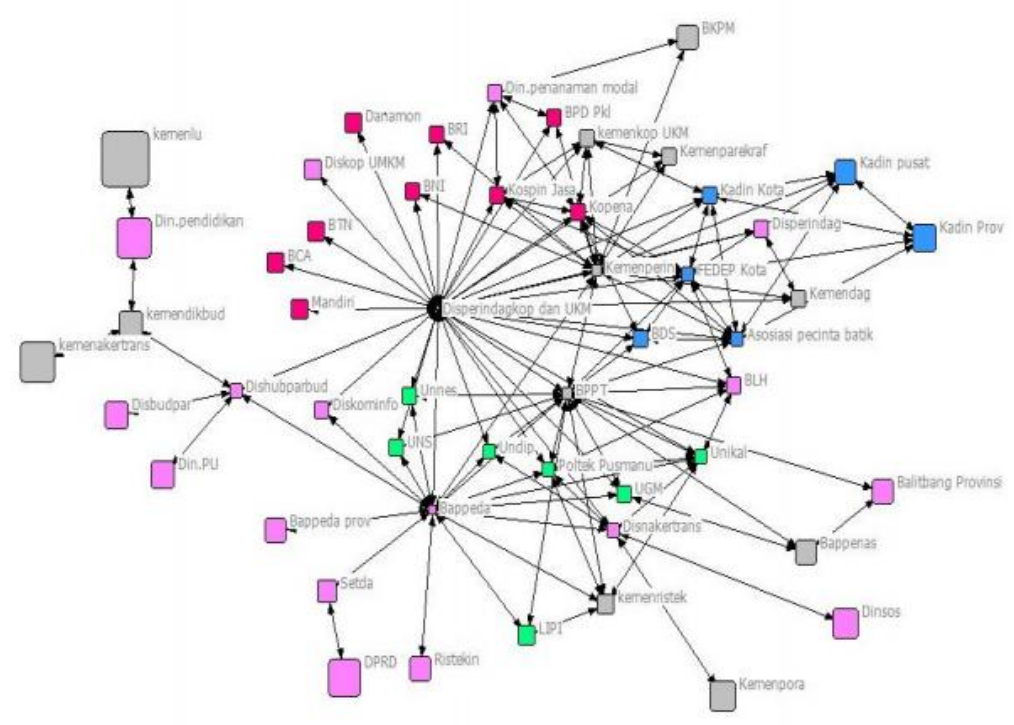

Keterangan

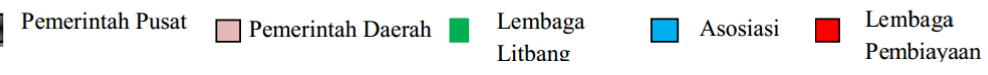

Gambar 4. Visualisasi Jaringan Antar Aktor dalam Klaster Batik pada Ukuran in Closeness Centrality

Disperindagkop dan UMKM, Bappeda, Kemenperin, BPPT, Dishubparbud, Fedep, Poltek Pusmanu dan Unikal memiliki kedekatan lebih dengan interaksi dalam jejaring dibandingkan dengan aktor lain. Lebih jelas dikarenakan Disperindagkop dan UMKM, Bappeda, Kemenperin, BPPT, Dishubparbud, Fedep, Poltek Pusmanu dan Unikal merupakan aktor dengan kapasitas dapat mendukung penuh dalam pengembangan klaster batik Kota Pekalongan. Sementara Dishubparbud, Fedep Kota, Poltek Pusmanu, Unikal merupakan aktor dengan peran mengkoordinasikan setiap kegiatan yang mendukung klaster batik melalui informasi dan pengetahuan secara umum terhadap aktor institusi lainnya.

3) Peranan aktor dalam pengembangan klaster batik

Pendekatan betweenness berpandangan bahwa aktor yang lebih sentral/ lebih penting jika ia sebagai (1) Perantara informasi dalam jaringan, (2) Seberapa banyak arus informasi yang terganggu karena seseorang berhenti menyampaikan informasi atau menghilang dari jaringan, (3) Sampai sejauh mana mungkin seseorang dalam mengontrol 
arus informasi karena kekeduannya dalam jaringan. Aktor atau nodes yang memliki nilai betweennes tinggi/sentral dalam jaringan sebagai penghubung dalam rantai jaringan yang memfasilitasi penyebaran informasi dalam jaringan. Hasil dari visualisasi betweenness centrality dapat dilihat pada Gambar 5 yang merupakan visualisasi dari seluruh data sampel yang di peroleh dari respoden.

Hasil analisis betweenness centrality untuk jaringan aktor terlihat di Tabel 5. Dari Tabel 5 terlihat bahwa dalam pengembangan klaster batik berdasarkan hubungan relasi dalam aliran informasi dan pengetahuan yang mempunyai nilai tertinggi adalah Disperindagkop dan UMKM, kedua adalah Bappeda dan ketiga adalah Dishubparbud. Ini menunjukkan bahwa ketiga aktor lembaga tersebut merupakan aktor penghubung/ perantara. Hal ini mengakibatkan bahwa ketiganya adalah aktor yang dominan dalam jaringan aliran informasi dan pengetahuan karena banyak aktor lembaga dalam jejaring bergantung kepada lembaga tersebut.

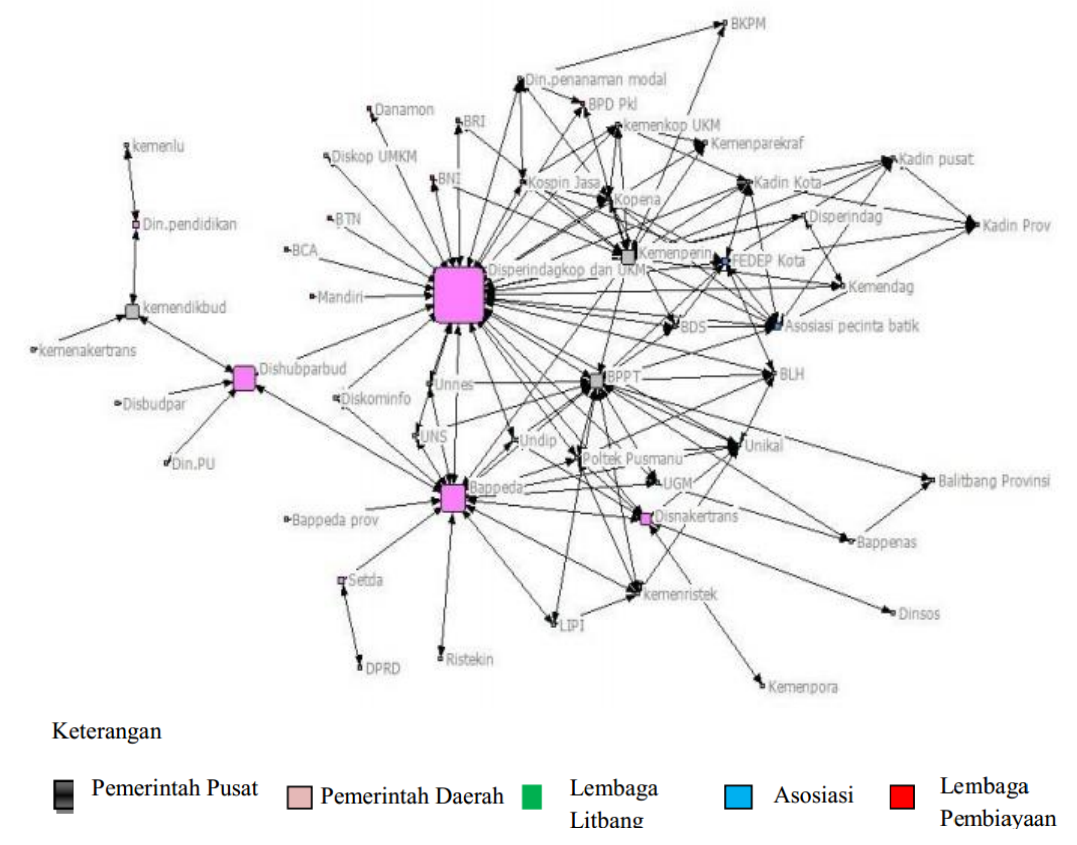

\section{Gambar 5. Visualisasi Jaringan Antar Aktor dalam Klaster Batik pada Ukuran in Betweenness Centrality}

Tabel 5. Hasil Perhitungan In-Betweenness Centrality Aktor Klaster Batik

\begin{tabular}{clcc}
\hline No & Aktor/ Lembaga & Betweeness & nBetweeness \\
\hline 1 & Disperindagkop dan UKM & 709,781 & 55,669 \\
2 & Bappeda & 311,173 & 24,406 \\
3 & Dishubparbud & 279,000 & 21,882 \\
4 & BPPT & 147,629 & 11,579 \\
5 & Kemendikbud & 146,000 & 11,451 \\
6 & Kemenperin & 139,509 & 10,942 \\
7 & Disnakertrans & 99,500 & 7,804 \\
\hline
\end{tabular}

Hasil analisis pada Tabel 5 menunjukkan bahwa aktor yang memiliki tingkat keterhubungan terbesar dalam jejaring adalah Disperindagkop dan UMKM dan Bappeda. Kedua aktor tersebut dikarenakan secara tugas pokok dan fungsi merupakan koordinator 
dalam mendukung tercapainya klaster batik yang dinamis untuk Kota Pekalongan. Karena fungsi kedua aktor tersebut adalah sebagai perantara maka tidak diragukan lagi bahwa dalam melakukan pengembangan klaster batik, sebagian besar aktor harus melalui koordinasi dengan Disperindagkop dan UMKM dan Bappeda.

Pengembangan dari klaster batik Kota Pekalongan ini tidak hanya dari pengusaha dan pengrajin batik saja, tetapi juga dari stakeholder yang semakin lama semakin berkembang. Interaksi antar aktor dalam klaster batik membawa hubungan yang lebih terbuka untuk peningkatan kapasitas sumberdaya dan berbagi informasi dan pengalaman dari proses pengembangan lokal. Hubungan dalam jaringan aktor klaster batik melalui pendekatan interaksi triple helix, menurut Hartanto (2004) triple helix adalah istilah dari bangun geometri yang terdiri dari tiga buah jalinan menyerupai susunan rantai DNA. Dikatakan triple helix model karena dalam klaster batik Kota Pekalongan ini ada tiga lembaga yang tergabung yaitu universitas, swasta, dan pemerintah serta lembaga pembiayaan. Klaster batik ini terdiri dari multi stakeholder. Untuk itu, diperlukan integrasi dalam aktivitas untuk membangun jaringan yang kuat sehingga memudahkan untuk berkoordinasi agar tidak berjalan sendiri.

\section{Analisis Sumber dan Aliran Informasi dalam Hubungan Antar Pelaku}

Penguatan klaster industri karena adanya penguatan kebutuhan akan modal sosial dan jaringan kerjasama antar aktor. Menurut Brouder dan Berry (2004) bahwa yang paling penting dalam pengembangan klaster adalah adanya penyediaan jaringan yang memadai sebagai sarana untuk berbagi informasi dan serta belajar dari masa lalu yang memiliki hubungan dengan modal sosial. Gambar 6 menunjukkan pola aliran informasi dalam klaster batik. Dari Gambar 6 terlihat bahwa penyebaran inovasi dalam pengembangan klaster batik yang ada di Kota Pekalongan terjadi cukup baik. Hasil skoring juga menunjukkan bahwa aliran informasi yang berasal dari konsumen memiliki nilai yang paling tinggi selanjutnya aliran informasi yang berasal dari sesama pengusaha, aliran informasi dari supplier, aliran informasi dari pemerintah, aliran informasi dari sekolah/ perguruan tinggi dan aliran informasi yang berasal dari paguyubanlah yang memiliki nilai rendah.

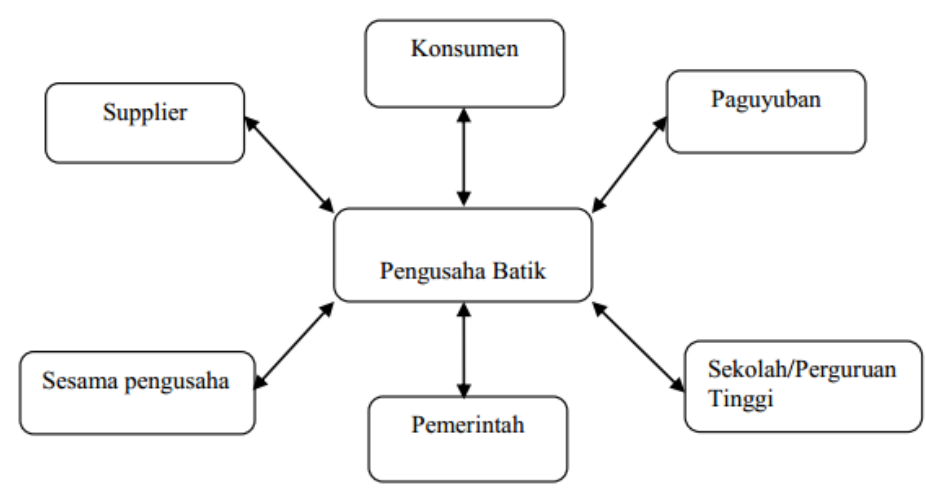

\section{Gambar 6. Pola Aliran Informasi dalam Aktivitas Klaster Batik}

Penyebaran pengetahuan ketrampilan maupun memberikan informasi mengenai proses produksi yang efektif dan efisien. Dukungan yang diberikan dalam membantu perkembangan usaha klaster batik tidak sekedar sebagai pelaku yang bergerak dalam bidang pendidikan saja namun juga membantu dalam hal teknologi kemudian untuk menyebarkan ilmunya diantara pengrajin batik. Universitas Pekalongan dan Politeknik 
Pusmanu yang selama ini bekerjasama dengan pengusaha untuk memberikan kemudahan dalam pembuatan batik.

Aliran informasi yang terjadi umumnya diperoleh dari pengusaha yang saling berinteraksi untuk memperoleh ide inovasi dari hasil pengamatan di pasar maupun dari pengusaha lain. Umumnya ide inovasi ini diperoleh melalui pertemuan formal maupun informal antar pengusaha batik dari aspek motif, pewarnaan dan model sesuai trend pasar kemudian ide tersebut dilanjutkan kepada karyawan baik dari pengrajin batik maupun pewarnaan sehingga mempunyai konsep yang sama. Gambar 7 berikut menyajikan mengenai aliran informasi dari proses inovasi klaster batik.

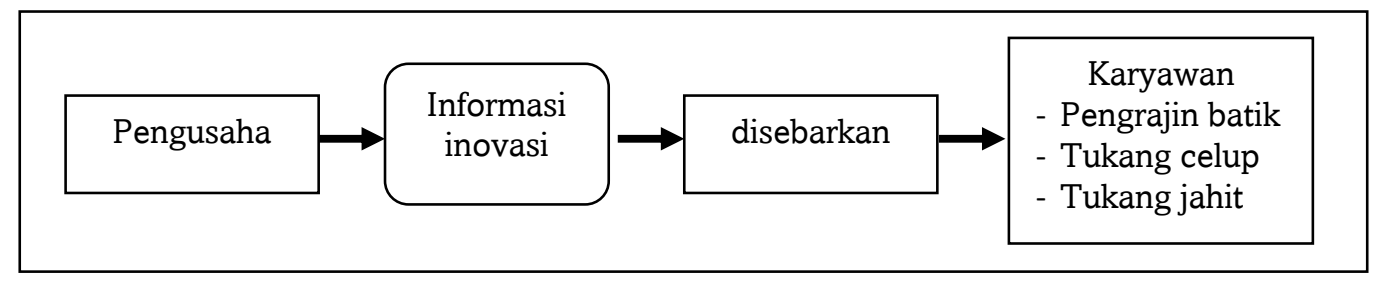

Gambar 7. Bagian Aliran Informasi dalam Aktivitas Klaster Batik

Aliran informasi dalam pengembangan klaster batik Kota Pekalongan masih ada yang belum efektif ini terlihat pada klaster Jenggot dan klaster ATBM Medono karena hubungan ini terhambat dalam koordinasi antara pemerintah dan pelaku usaha dimana pelaku usaha relatif individual sehingga terhambat pada komunikasi untuk transfer informasi dan pengetahuan. Peran paguyuban dalam klaster ini juga belum terlihat optimal karena pertemuan-pertemuan rutin antar pelaku usaha jarang terjadi. Sedangkan untuk klaster batik Pesindon, Kauman dan klaster ATBM Medono aliran informasi sudah berjalan optimal dan perlu lagi ditingkatkan agar hubungan yang terjadi dalam jaringan aktor bisa menjadi bentuk kolaborasi yang baik antar pemerintah, pelaku usaha dan asosiasi terkait, akademisi serta lembaga pembiayaan. Untuk itu, guna membangun jejaring kerjasama antar pelaku dalam pengembangan klaster diperlukan adanya keterkaitan dan aliran informasi untuk menciptakan pengetahuan baru yang mampu bersaing baik di wilayah lokal maupun kota batik lainnya. Dalam aktivitas proses inovasi klaster yang terjadi untuk membangun komitmen antar pelaku diperlukan interaksi satu sama lain.

Salah satu faktor dalam kesuksesan pengembangan klaster industri adalah adanya aliran formal dan informal dari pengetahuan yang didapat dari hubungan antar pelaku klaster. Pada suatu industri dalam klaster, aliran informasi dan pengetahuan memiliki peranan yang penting, karena dengan adanya informasi dan pengetahuan akan memperkuat interaksi antar aktor dalam meningkatkan pertumbuhan industri dalam klaster. Morosini (2004) mengungkap bahwa suatu pengetahuan baru yang diperoleh industri/pelaku klaster industri pada gilirannya akan mengarahkan pada suatu gagasan baru. Pengetahuan baru akan mudah terbentuk jika industri-industri, lembaga riset/perguruan tinggi, dan lembaga pendukung lainnya mempunyai kedekatan geografis tertentu. Dalam aliran informasi dan pertukaran pengetahuan dalam klaster akan dapat memudahkan dalam bertukar informasi dan mendapatkan inovasi dan teknologi yang berdampak dalam peningkatan produktivitas produk batik.

Pengembangan klaster batik akan lebih efektif bila aliran informasi dan pengetahuan dilakukan melalui interaksi antar aktor. Hal ini serupa dengan pendapat Darroch (2005) dan Corsaro et al. (2012) bahwa keterlibatan berbagai aktor serta informasi dan pengetahuan yang tersebat mampu mengembangkan jaringan yang inovatif. Dalam hubungan antar 
aktor klaster batik dapat memfasilitasi terjadinya kerjasama dan berbagi informasi dan pengetahuan, sehingga didalamnya akan terjadi proses bisnis. Skema di Gambar 8 menunjukkan model transfer informasi yang efektif dalam pengembanga klaster batik Pekalongan. Jaringan aktor dalam klaster batik ini terdapat peluang yang dapat dimanfaatkan secara optimal untuk mengetahui perkembangan terkini dari klaster batik yang saling berinteraksi sesuai dengan peran masing-masing aktor yang terlibat. Aktor dalam klaster akan saling tukar informasi dengan tujuan untuk belajar bagaimana cara melakukan sesuatu secara lebih baik. Pertukaran pengetahuan dan pengalaman atau praktik terbaik yang dilakukan oleh pemerintah, perguruan tinggi, fedep, forum rembug klaster, paguyuban dan asosiasi batik diharapkan mampu mengatasi masalah dalam klaster.

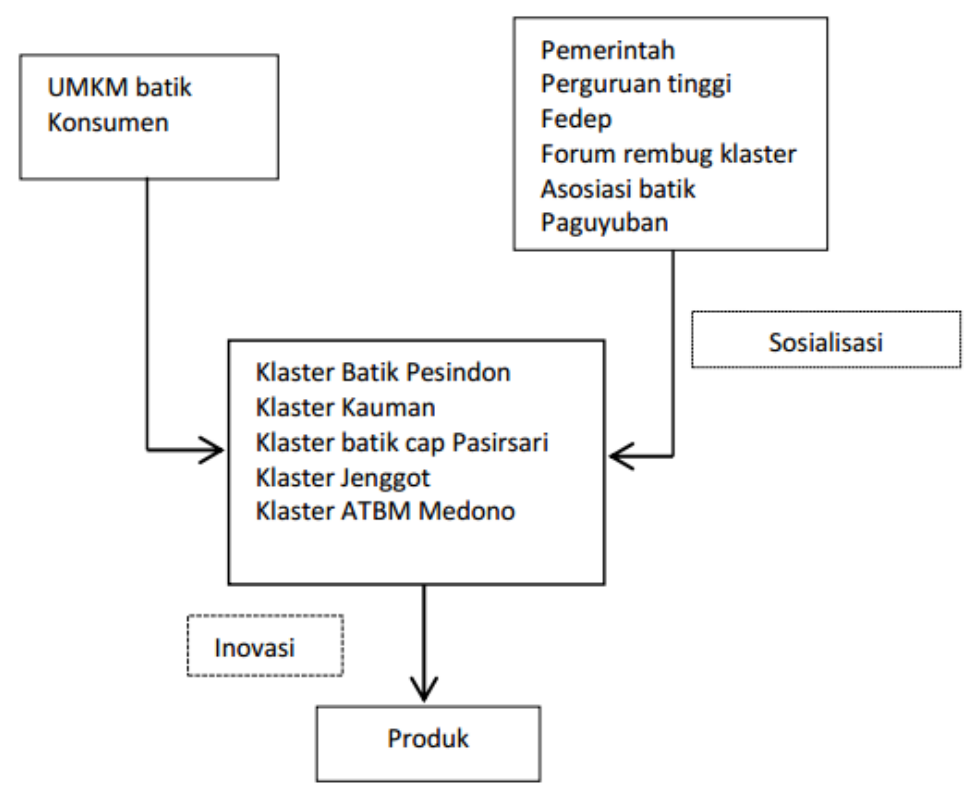

Gambar 8. Transfer Informasi Dan Pengetahuan yang Efektif dalam Klaster Batik

\section{Kesimpulan dan Rekomendasi}

Keterlibatan banyak pihak yang menunjang aktivitas klaster batik ini merupakan salah satu keberhasilan pelaksanaan klaster di daerah, karena selain industri terkait yang terlibat dalam pembuatan batik termasuk dari kerjasama pemerintah, pelaku usaha, asosiasi, perguruan tinggi dan lembaga keuangan. Klaster di kampung batik Kota Pekalongan ini tidak semua berkembang dengan baik walaupun ada bantuan dari pemerintah, pembentukan forum klaster. Hal ini disebabkan belum adanya kerjasama baik antar pengusaha batik tersebut karena masing-masing pengusaha berjalan sendiri-sendiri. Untuk itu, diperlukan pembentukan jaringan aktor dan jejaring kerjasama yang kuat dengan semua yang berkepentingan akan memudahkan dalam penyampaian aspirasi. Intensitas hubungan relasi antar aktor akan mendorong klaster berkembang lebih dinamis. Hubungan relasi antar pelaku dalam klaster sesuai dengan jaringan kerjasama melalui jaringan sosial bahwa yang mempunyai peranan paling utama dalam pengembangan klaster batik meliputi Disperindagkop dan UMKM, Bappeda, Kementerian Perindustrian, BPPT dan Fedep Kota Pekalongan. Disperindagkop dan UMKM berperan sebagai pusat informasi dari pelaku usaha dan aktor lainnya baik dari pemerintah maupun lembaga pendukung lainnya. Sementara itu, pemerintah daerah perlu memfasilitasi pembentukan Unit Kerjasama 
Klaster, dalam bentuk institusi ataupun wadah yang khusus untuk mengelola klaster industri batik di Kota Pekalongan yang terdiri dari perwakilan dari unit usaha batik dan industri terkait dengan dibagian hulu dengan hilir, serta perwakilan dari pemerintah, lembaga pendidikan dan pelatihan, lembaga keuangan, serta lembaga bantuan, sehingga menciptakan iklim sinergi antar pelaku yang baik.

Rekomendasi untuk mendukung hubungan jejaring aktor dalam klaster batik dalam menunjang aktivitas klaster industry, meliputi perlunya memperhatikan modal sosial dan jejaring sosial yang membentuk interaksi antar aktor untuk meningkatkan hubungan kerja sama sehingga dapat membangun persaingan yang positif, penguatan kelembagaan dalam pengembangan klaster batik yang inovatif, serta menjaga hubungan jaringan kerjasama yang sudah terbentuk baik dengan pemerintah daerah, pemerintah pusat, swasta, akademisi, lembaga pembiayaan.

\section{Daftar Pustaka}

Astuti, Y. (2009). Pengembangan inovasi dalam klaster batik Pekalongan (Unpublished master's thesis). Program Studi Magister Pembangunan Wilayah dan Kota, Universitas Diponegoro, Semarang.

Badan Pengkajian dan Penerapan Teknologi (BPPT). (2003). Panduan pengembangan klaster industri unggulan daerah. Jakarta: Badan Pengkajian dan Penerapan Teknologi.

Blakely, E. J. (1994). Planning local economic development (Theory and practice). California: Sage Publications Inc.

Bohlmann, J. D., Calantone, R. J., \& Zhao, M. (2010). The effects of market network heterogeneity on innovation diffusion: An agent-based modeling approach. The Journal of Product Innovation Management, 27(5), 741-760. doi:10.1111/j.1540-5885.2010.00748.x.

Brouder, A. M., \& Berry, L. (2004). Sustainable business clusters in the regions (Regional Futures Research Report February 2004). Retrieved from http://old.tcinetwork.org/media/asset_publics/resources/000/000/709/original/SustainableBusinessClustersRepo rt.pdf.

Corsaro, D., Cantù, C., \& Tunisini, A. (2012). Actors' Heterogeneity in Innovation Networks. Industrial Marketing Management, 41, 780-789. doi:10.1016/j.indmarman.2012.06.005.

Daly, E., \& Haahr, M. (2007). Social network analysis for routing in disconnected delay-tolerant MANETs. Proceedings of the $8^{\text {th }}$ ACM International Symposium on Mobile ad hoc Networking and Computing, 3240. doi:10.1145/1288107.1288113.

Darroch, J. (2005). Knowledge management, innovation and firm performance. Journal of Knowledge Management, 9(3), 101-115. doi:10.1108/13673270510602809.

De Fretes, F., Utomo, W. H., \& Manongga, D. (2012). Application of Social Network Analysis for Mapping Patterns of the Learning Process in LPIA Tambun. International Journal of Computer Science, 9(3), 9197.

Han, Z. (2009). A model of clustering process in low income economies. International Journal of Business and Management, 4(12), 46-51. doi:10.5539/ijbm.v4n12p46.

Hanneman, R. A., \& Riddle, M. (2005). Introduction to social network methods. Riverside, CA: University of California.

Hartanto, A. (2004). Strategi clustering dalam industrialisasi Indonesia. Yogyakarta: Penerbit Andi.

Morosini, P. (2004). Industrial Clusters, Knowledge Integration and Performance. World Development, 32(2), 305-326. doi:10.1016/j.worlddev.2002.12.001.

Mulyana, D. (2005). Ilmu komunikasi suatu pengantar. Bandung: Remaja Rosdakarya.

Oerlemans, L. A. G., Meeus, M. T. H., \& Boekema, F. W. M. (2001). Firm clustering and innovation: Determinants and effects. Papers in Regional Science, 80, 337-356. doi:10.1111/j.14355597.2001.tb01803.x.

Porter, M. E. (1990). Competitive advantage of nations. New York: Free Press. 


\section{Hubungan dan Aliran Informasi Antar Pelaku pada Klaster Batik Kota Pekalongan}

Rodan, S., \& Galunic, C. (2004). More than network structure: How knowledge heterogeneity influences managerial performance and innovativeness. Strategic Management Journal, 25(6), 541-562. doi:10.1002/smj.398.

Susanty, A., Handayani, N. U., \& Jati, P. A. (2013). Analisis faktor-faktor yang mempengaruhi pertumbuhan klaster batik Pekalongan (Studi kasus pada Klaster Batik Kauman, Pesindon dan Jenggot). J@TI Undip, $8(1), 1-14$

Zuhal. (2013). Gelombang ekonomi inovasi: Kesiapan Indonesia berselancar di era ekonomi baru. Jakarta: PT.Gramedia Pustaka Utama. 